\title{
Charting African Higher Education- Perspectives at a Glance
}

\author{
Damtew Teferra
}

\begin{abstract}
Higher education in Africa is undergoing a transformation wrought by massive expansion, which has implications for every facet of the sector. What makes Africa's growth unique is that it has seen a "flash flood" of growth with consequent implications that range from quality to funding, from governance to employment. Ironically, however, despite this massive growth, the system still remains the world's least developed. This introduction to the International Journal of African Higher Education's inaugural issue is intended to capture the state of higher education around the themes featured in this volume, based on recent as well as in-press sources.
\end{abstract}

L'enseignement supérieur en Afrique connaît une transformation provoquée par une expansion massive, qui touche de nombreux aspects de ce secteur. Ce qui rend la croissance africaine unique, c'est sa rapidité qui engendre des conséquences qui vont de la qualité au financement, de la gouvernance au recrutement. Ironiquement, malgré cette croissance massive, le système reste le moins développé du monde. Cette introduction au premier numéro du Journal International sur l'Enseignement Supérieur en Afrique a pour objectif de présenter la situation de l'enseignement supérieur autour de thèmes abordés dans ce numéro. Cet article est basé sur des recherches récemment publiées ou encore sous presse.

\section{Introduction}

A plethora of development players, policy makers, and relevant organisations-from the World Bank to the Organisation for Economic Cooperation and Development (OECD), from the African Development Bank (AfDB) to the African Union (AU), and from the Association of African Universities (AAU) to the Association for the Development of Education in Africa (ADEA) - all concur that higher education must be 
centrally placed in the strategic development plan of nations for a meaningful and sustainable economic development to take hold. African higher education has undergone some tumultuous and difficult periods of policy development, but the present moment, in the short lifespan of Africa's modern higher education system, may be the continent's second high season.

Whether by design or popular demand, "massification" of higher education is the hallmark of the sector in virtually all parts of the world. Countries around the world are striving to build their higher education systems to meet mounting demand, as is the case in Africa, or as part of their strategic development plan, as is the case in the developed and emerging countries. Unquestionably, building a strong higher education system is not a luxury for which countries can be chastised for indulging, but a national imperative that is critical for national development and global competitiveness.

What does national development and global competitiveness actually mean in the context of African higher education development? To put it simply and directly, African higher education has never been a luxury, despite suffering misrepresentation as such-for the teachers, educators, doctors, engineers, economists, accountants, managers, and policy analysts for the continent-to mention only a few of the leaders any nation needs-must be produced in that institution. It is simply not conceivable to contemplate a nation without such crucial expertise in a country; and therefore the development of higher education in every country, to reiterate, is crucial.

In the current highly dependent and competitive global socioeconomic environment, producing such expertise in large numbers and high grade is vital. In the knowledge society, it is not simply the volume of knowledge produced that counts; rather quality and currency of knowledge matter tremendously. As a consequence, countries in both the developed and the developing world are under heavy pressure to cater to that trend.

With the world moving increasingly toward a knowledge economy, tertiary education can help economies keep up or catch up with more technologically advanced societies. Higher education graduates are likely to be more aware of and better able to use new technologies. They are also more likely to personally develop new tools and skills. Their knowledge can also improve the skills and understanding of non-graduate co-workers, while the greater confidence and know-how inculcated by advanced schooling may generate entrepreneurship, with positive effects on job creation. Tertiary schooling can also have indirect benefits for economies. By producing well-trained teachers, it can enhance the quality of primary and secondary education systems and give secondary graduates greater opportunities for economic advancement. By training physicians and other health workers, it can improve a society's health, raising productivity at work. And by nurturing governance and leadership skills, it can provide countries with the talented individuals needed to establish a policy environment favourable to growth. Setting up robust and fair legal and political institutions and making them a part of a country's fabric is an obvious example of the need for advanced knowledge and decision-making skills. But equally demanding in the economic sphere is developing a culture of job and business creation. Addressing environmental problems and improving security against internal and external threats also place a premium on the skills that advanced education is best placed to deliver (Bloom, Canning, Chan, \& Luca, in this issue).

Buoyed by new favourable policies and also pressure from the pretertiary sector, countries have registered huge gains in terms of access to higher education. While growth has been universal the region over, some countries have shown phenomenal expansion, if not in gross enrolment ratio but absolute figures. In Tanzania, student enrolment in public and private universities increased from 3I,674 in 2003-2004 to 135,365 in $2010-2011-a 327 \%$ increase. At the University of Dar es Salaam while applicants grew from 5,325 (in 2002-2003) to 17,287 (2009-20I0), the number of students admitted grew from 2,0I5 (in 2002-2003) to 6,952 (2009-2010) (Ishengoma, in press; 2013). In Senegal, the enrolment at UCAD grew from 24,780 in 200 I to 74,250 in 2012 (Sall, in press) -also a more than $300 \%$ growth. The figure for Uganda is also remarkable. It grew from c. 20,000 in 200I (Musisi, 2003 ) to close to 180,000 in 2011 (Oboko, 20I3). In Ethiopia, the absolute growth has been simply breath-taking-from 79,000 in I99I to more than 600,000 students in the higher education system in 2012 (Ayalew, in press).

Accompanying this encouraging and remarkable growth in numbers, however, have been considerable variations in enrolment. According to Goolam (in this issue), in 2009, while the overall gross enrolment ratio for Sub-Saharan Africa was about $7 \%$, that ratio was as low as $0.5 \%$ for Malawi, 2.0\% for Chad and Eritrea, 2.5\% for Central African Republic, and $2.7 \%$ for Burundi. While these countries show a need for significant improvement, other countries showed promisingly higher ratios-for example $26 \%$ for Mauritius and $15 \%$ for Cape Verde, Botswana, and South Africa (UIS, 20Io; figures rounded up).

Even with this massive growth, the irony for Africa remains; it needs 
to do even more if it is to catch up with the rest of the world. This need is particularly pressing as knowledge becomes central to development and national competitiveness. Standing squarely in the centre of that need for knowledge production are universities. The challenge, however, is serious: The growth of African higher education, for the most part, has not been coupled with the requisite quality demanded and expected of higher learning.

\section{The Equity Picture}

Goolam and Darvas et al. (both in this issue) emphatically stress that the higher education system in Africa is not only unequal across countries and sub-regions, but it is also massively inequitable. The main areas of inequities are associated with economic status, gender, and origin (urban/ rural). To bring this picture to life, Darvas et al. state:

In $3 / 4$ th of the [African] countries, youth from the wealthiest households occupy over $50 \%$ of spaces in tertiary education and youth from the top two wealth quintiles occupy nearly $80 \%$ of tertiary spaces. Individuals from the poorest households are five times less likely to have access to tertiary education than individuals from the richest households. As a result, the overall Gross Enrolment Ratio (GER) in tertiary education is strongly determined by the GER of the highest income quintile in most countries.

As one extreme case, 91.9\% of students in Malawi's higher education system come from the highest income bracket while the lowest income bracket has less than I\% representation (World Bank, cited in Dunga, 2013).

On the gender front, inequity varies considerably by institutional ownership (public vs. private), status of institutions (either "flagship" or "brand-new"), academic programs, and academic hierarchy. A disproportionate number of female students are represented in private programs in both public and private institutions. They also tend to aggregate more in "soft" sciences-in social studies, arts, and humanities. Furthermore, at the academic profession, they are represented even less, and their numbers dwindle even more at the highest rung of the academic ladder and leadership. In Nigeria, a country with one of the much robust higher education system in Africa, Bola (in press) documents: "In the 20II/I2 session, the academic staff strength of Ibadan was I,4I 6 , reflecting an overall growth rate of $6 \%$ over a 20 -year period since the corresponding figure in the $1992 / 93$ session was 1,334 . Although the proportion of female staff grew from $18 \%$ to $27.6 \%$ over the period, women are very much underrepresented in the professoriate, particularly in the fields of Technology, Humanities and the Social Sciences."
According to Sifuna (in press) enrolments in the Kenyan public universities in 2006 showed that female students, as in previous years, represented around 30\% of the total enrolment. Despite the general under-representation of female students, their numbers grew fairly steadily in I990s. In Ethiopia, while the volume of female undergraduate and graduate students increased, the proportion of male students is increasing even more rapidly, creating a greater gap between the two. The growth trajectory begins with $2 \mathrm{I} .6 \%$ (of a total of 67,682 ) in I99I and a percentage increase of $26.7 \%$ (of a total of 5 I9, 770 ) to 2012 for undergraduate students. The graduate picture shows comparable figures of growth from 2 I.2\% (of a total of II, 627 ) in I99I to $24.6 \%$ (of a total of 83,65I). The staff figure is even more dismal; it has shown minimal growth from 6.I\% (of a total of 2,503) in I99I to $9.6 \%$ (of a total of 20,822) in 2012 (Ayalew, in press).

Inequity is however not a phenomenon consistent across the board-in a few countries such as South Africa, Namibia, Botswana, and Mauritius and North African countries, the proportions are at par, or even higher, for female numbers. In Botswana the proportion of female students stands at $48 \%$; when however the Science, Technology, and Engineering figure is excluded, the female figure stands higher at $52 \%$ (Kotecha, 2OI2). For instance, at the University of KwaZulu-Natal, South Africa two-thirds of the students who graduated in 2013 were female. Needless to say, such massive disparities in either case, are not inherently healthy for society at large.

\section{The Financing Conundrum}

The massive expansion witnessed in the region has not been supported by appropriate resources—human, financial, and material—with major consequence for the quality of the system. To be sure, numerous countries have increased their budget for education, including higher education, but these resources are not commensurate with the size of expansion.

According to the World Bank (2010), Africa has maintained its public investment in higher education over the last I5 years, allocating approximately $0.78 \%$ of its gross domestic product (GDP) and around $20 \%$ of its current public expenditure on education to this sector. However, during this period, the total number of students pursuing higher education tripled, climbing from 2.7 million in I991 to 9.3 million in 2006 (an annual average increase rate of $\mathrm{I} 6 \%$ ) to now more than Io million, while public resources allocated to current expenditure in that sector only doubled (an annual average increase rate of 6\%). The situation is even more dire in Africa's poorest countries, which allocate approxi- 
mately $0.63 \%$ of GDP to higher education, and where the number of students quadrupled from I99I to 2006 while available public resources in general only increased by $75 \%$ at most.

Darvas et al. also reinforce the conclusion that, while the figures have shown growth, allocation by GDP remains distressingly low. This funding discrepancy has direct implications on the effect of the massive expansion, spreading resources so thin that the services and quality have suffered considerably. In one extreme case from Zambia, for instance, the universities received only $20 \%$ of their projected expenditure from the government (Masaiti, 2013).

Africa is facing the dual challenge of expanding access while striving to raise quality in higher education. Both challenges necessitate considerable resources for a sustained period of time (Teferra, 20I3). According to the World Bank's (20I0) estimate, approximately US\$45 billion (value in 2006) was needed to increase the capacity of institutions between 2006 and 2015 to meet the need for public higher education as a whole, of which US\$20 billion is needed for low-income countries.

One of the other most common patterns in Africa is the poor finance base of higher education systems virtually across the board. This deplorable condition is well known; but a related issue that has received little attention has been the ineffective and inefficient way of deploying available resources. Higher education policies implemented in Francophone African countries allow universities to admit students without reference to minimum quality standards and to allocate a significant portion of their budgets to student social support, including scholarships, accommodation, catering, transport, and health coverage. In Senegal for instance, $70 \%$ of the operating budget of universities is allocated to student social support, leaving limited resources that can be devoted to the maintenance of even minimum quality standards. The projected figures for new-student admissions in the coming years will further reduce the capacity of universities to assure quality of higher education (Juma et al., in this issue; see also Teferra, 20I3.)

Another little-addressed marker of waste in resources is the problem of haemorrhage through student drop out. In 2006 , for instance more than $50 \%$ of the students who entered the University of Antananarivo, Madagascar, dropped out after the first year; for the faculties of medicine and law at that university, the dropout rate for first-year students was between 55 and 60\% (Randriamahenintsoa, 2013).

In this age of cost-sharing and resource mobilisation, it is still customary in many African institutions to return unused budget and funds, including self-generated, to the national treasury at the end of the financial year, hampering incentives for institutions to gener- ate their resources or even to deploy them strategically. For instance, in 2008-2009, Addis Ababa University used only I0\% of the US\$1 million budget allocated to research and development. Yigezu (2013) attributes this situation to inefficient financial management, poor planning, feeble institutional capacity, cumbersome bureaucracy, and weak institutional autonomy.

\section{The Scope of Internationalisation}

The importance of the internationalisation of higher education, in the era of the knowledge economy, has been growing by leaps and bounds for its anticipated contribution to quality higher education, promotion of research, regional/global integration, and fostering human resource capacity. The elements of internationalisation-i.e., mobility of scholars and students, regional and international networks, quality regimes (accreditation and ranking bodies), curricular reform, research initiatives, publication and communication (journals and databases), and new forms of educational delivery-pose new challenges, opportunities, and risks to the higher education system around the world. This situation especially prevails in Africa, as the weakest player in the internationalisation of higher education.

In terms of mobility, with I94,000 international students, SubSaharan Africa accounted for $8 \%$ of the global total. The Sub-Saharan countries that sent the most students abroad were Zimbabwe (I7,000), Nigeria (I5,000), Cameroon (I5,000), and Kenya (I4,000); $51 \%$ of these students went to Western Europe. Their second most important destination was Sub-Saharan Africa (2I\%) followed by North America (20\%). Nine out of Io international students who stay in the region go to South Africa, especially those from the Southern African countries: Botswana, Malawi, Namibia, Swaziland, Zambia, and Zimbabwe. In addition to South Africa, Ghana, Egypt, and Uganda have also emerged as important recipients of international students, particularly from within Africa (UNESCO, 2006; cited in Mulumba et al., 2008). France remains a more attractive destination of choice for students from French-speaking African countries.

The movement of African students within the continent is limited. The only meaningful regional hub of scholarship for Sub-Saharan African students still remains South Africa owing to a number of factors: better equipment, higher quality staff, cheaper cost of study, more relevant curricula, preferred instructional medium, and better chance of return.

Sehoole and de Wit (in this issue) hold that innovations and alternative views about internationalisation should not be dominated by the 
traditional hegemony of "Western" concepts and strategies but instead require an autonomous and refreshing approach for the emerging and developing countries and regions. Two aspects are central in that approach: increased regional and South-South cooperation, and more attention to strategies that build on the social responsibility and civic engagement role of higher education.

Indeed, the conventional dominance of western concepts and strategies and the effort to boost South-South cooperation are not new perspectives in the international higher education arena. But with a more assertive and economically stronger South against the background of the economically ailing North, the possibilities and chances of the oft-cited yearning seem to be more likely than ever.

It is exactly in recognition of these underlying unpopular policies and paradigms, which still pervade the 2ist century, that the Paris Declaration (2005) and Accra Agenda for Action (2008) were developed to foster mutual benefits between all the parties of partnership. The accords were founded on five core principles: joint ownership, alignment, harmonisation and results, and mutual accountability in development cooperation. They are gaining slow but steady traction in shaping the development cooperation landscape, including in international higher education. Regardless of the effort in describing the inherent ecology of the international relationship, the hard fact is that the old institutions, paradigms, and instruments of global engagement have become archaic, even dangerous, in ensuring the collective survival of the global community (Teferra, 20I4).

\section{Quality Control}

The conversation on quality and quality regimes (such as quality framework, quality assurance, accreditation, among others) has become more prominent and vocal with the expansion of higher education in the region and particularly with the proliferation of private providers. These developments have been instrumental in the establishment of quality control mechanisms in many countries. By 20I2, according to Juma, Okebukola, and Olusola (in this issue), 2I African countries had legally established quality assurance agencies and a dozen other countries were at relatively advanced stages in this direction. Though Francophone Africa is lagging behind, it partially fills that gap by reliable quality assurance mechanisms through voluntary processes of external evaluation by the Conseil Africain et Malgache de l'Enseignement Superieur (CAMES, the African and Malagasy Council of Higher Education). The Inter University Council for Eastern Africa (IUCEA) is another regional body with responsibility for ensuring internationally comparable stan- dards in the five partner states of the East African Community: Burundi, Kenya, Rwanda, Tanzania, and Uganda.

One of the most confounding problems of the higher education landscape in Africa is the fast decline of higher education quality. Its long list of challenges is not unknown; they span from funding to institutional leadership, from lack of competent academic staff to poorly prepared students. Indeed, with such massive expansion of the system, it may not be surprising that the quality of higher education has deteriorated precipitously.

The imperatives to improve the quality of higher education thus are simply enormous, especially because knowledge production has become critical for national development and global competitiveness in the 2ist century. The challenge for African higher education is not thus simply in catching up with the rest of the world in terms of the numbers that needed to be produced; rather, of equal importance is the quality and currency of knowledge that needs to be generated. It is in recognition of these major knowledge shortfalls that a number of initiatives are being undertaken-from consolidating quality regimes, to establishing centres of excellence, supporting post-graduate expansion and its consolidation.

\section{Graduate Education}

As the discussion to this point establishes, the encouraging and optimistic expansion has characterised the most recent stage of African higher education; but it should be noted that this expansion has occurred mainly in undergraduate studies. The expansion in post-graduate studies remains dwarfed by comparison. For instance, Ethiopia, which has recorded phenomenal enrolment growth that has now surpassed 600,000 students, includes only $5 \%$ graduate students in its system (MOE, 2OI2-2OI3), a statistic that has huge implications for quality.

According to Hayward and Ncayiyana (in this issue quoting ASSAF, 20I0), figures on graduate enrolment from ig higher education institutions in Africa between 1997 and 2007 show a total of $\mathrm{I} 69,275$ graduate students studying for master's degrees and PhDs, or $6.9 \%$ of the total enrolment at that time. The data from 2010-2013, though incomplete, show an increase of graduate students to a total of 294,339 (now $9.3 \%$ of the total enrolment at these institutions), an increase of $73.9 \%$. While this increase over approximately five years is quite substantial, slightly more than half of it (50.2\%) is occurring in South Africa. Of this total number of graduate students, approximately $20 \%$ were studying at the $\mathrm{PhD}$ level, with $80 \%$ at the master's level. Of those studying for a $\mathrm{PhD}$ in South Africa, 338 were from other Sub-Saharan African countries in 
2007-an increase from only 86 in 2000.

Lofty and ambitious - and sometimes unrealistic - plans of African countries to expand their graduate programs, especially in science, technology, and engineering, are explicit in their higher education strategic plans. The wish lists of plans, objectives, activities, and deliverables speak to their deep-seated interest in expanding the state of graduate studies and high-end research. Ethiopia, for example, planned to produce 5,000 PhDs in Io years - a very ambitious plan given the current state of the higher education system. Now more than halfway through the allotted decade, it has not produced a fraction of that number. In Nigeria, Ibadan University, the country's flagship university, has produced 5,000 doctoral graduates since it graduated its first students in I952 - a total that averages out to 80 a year (Bola, in press).

According to IAU's (2010) study based on six universities in SubSaharan Africa, the challenges to graduate studies are numerous. For example, at the government level there is a lack of national policy on or political commitment to research and inadequate capacity to cope with the rising demand. At the institutional level, IAU identified a lack of coherent research policies and strategies; inadequate infrastructure; poor, unreliable, and expensive Internet connectivity; poorly stocked libraries and poorly equipped labs; and a shortage of supervisors. Without doubt the most critical challenge to graduate program development in Africa remains limited resources at the disposal of institutions grappling with the massive expansion in enrolments. While money may not be the panacea for all the challenges, it most certainly plays a critical role in the development of graduate education.

As one of the strategies to boost graduate education and also develop the requisite teaching and research capacity, a number of "centres of excellence" are being established in the region by different players. These include the African Union's initiative of the Pan African University as well as those supported by the World Bank and one being effected by DAAD. Furthermore, a number of field-specific specialisations in Africa-in agriculture, economics, and mathematics, among others-are being established and/or consolidated.

\section{Conclusion}

This introduction to the International Journal of African Higher Education's inaugural issue is intended to capture the state of higher education around the themes featured in this volume, based on recent as well as in-press sources. Thus, it is not an exhaustive thesis on African higher education. Despite this tight focus, one generalisation crosses all fields: Higher education in Africa is undergoing a transformation wrought by massive expansion, which has implications for every facet of the sector.

The larger context is that growth in higher education enrolment is a global phenomenon. What makes Africa's growth unique, however, is that it has seen a "flash flood" of growth with consequent implications that range from quality to funding, from governance to employment. Ironically, however, despite this massive growth, the system still remains the world's least developed. This means that Africa must do more in facing the dual and contradictory challenges of increased expansion and improved quality.

Higher education is key and critical to sustainable socio-economic development; this recognition has recently taken the sector to an unprecedented status at the global level. Thus the expansion, development, and consolidation of a higher education system in the region, which is at once locally responsive and globally competitive, are not simply necessities, but mandatory tasks of tremendous challenge.

\section{References}

Ayalew, E. (in press). Addis Ababa University. In D. Teferra (Ed.), Flagship universities in Africa: Achievements, successes, and potentials. Durban, South Africa and Boston, Massachusetts, USA: International Network for Higher Education in Africa (INHEA).

Bola, U. (in press). University of Ibadan. In D. Teferra (Ed.), Flagship universities in Africa: Achievements, successes, and potentials. Durban, South Africa, and Boston, Massachusetts, USA: International Network for Higher Education in Africa (INHEA).

Dunga, H. S. (2013). Financing higher education in Malawi: Prospects, challenges, and opportunities. In D. Teferra (Ed.), Funding higher education in Sub-Sahara Africa (pp. I84-213). London: Palgrave Macmillan.

IAU. International Universities Association. www.iau-aiu.net

Ishengoma, J. (in press). University Dar es Salaam. In D. Teferra (Ed.), Flagship universities in Africa: Achievements, successes, and potentials. Durban, South Africa, and Boston, Massachusetts, USA: International Network for Higher Education in Africa (INHEA).

Ishengoma, J. M. (20I3). Funding higher education in Tanzania: Modalities, challenges, prospects and a proposal for new funding modalities. In D. Teferra (Ed.), Funding higher education in SubSahara Africa (pp. 2I4-246). London: Palgrave Macmillan.

Kotecha, P. (2OI2). A profile of higher education in Southern Africa, Volume 2: National perspectives. Retrieved on May Iо, 20I4, from http:// www.sarua.org/files/publications /SARUA\%2oleadership\%20 Dialogue\%2oSeries /SARUA\%2oProfiles\%2oof \%2०HE\%2० 
Vol\%202.pdf.

Masaiti, G. (20I3). Students' perceptions of financing public universities in Zambia: Toward a more sustainable and inclusive policy strategy. In D. Teferra (Ed.), Funding higher education in Sub-Sahara Africa (pp. 296-326). London: Palgrave Macmillan.

MOE. Annual Report. Ministry of Education, Ethiopia. (20I2-20I3).

Mulumba, M. B., Obaje, A., Kobedi, K., \& Kishun, R. (2008). International student mobility in and out of Africa: Challenges and opportunities. In D. Teferra \& J. Knight (Eds.), Higher education in Africa: The international dimension (pp. 490-5I4). Boston, Massachusetts, USA, and Accra, Ghana: CIHE and AAU.

Musisi, N. (2003). Uganda. In D. Teferra \& P. G. Altbach (Eds.), African Higher Education: An international reference handbook (pp. 6II-623). Bloomington, Indiana, USA: Indiana University Press.

Oboko, M. B. (2013). Funding of higher education in Uganda: With special emphasis on donors and contribution of national communities approaches. In D. Teferra (Ed.), Funding higher education in Sub-Sahara Africa (pp. 247-275). London: Palgrave Macmillan.

OECD. Paris Declaration and Accra Agenda for Action. Retrieved on June I, 20I4, from http://www.oecd.org/dac/effectiveness/parisdeclarationandaccraagendaforactionfullrelateddocumentation.htm.

Randriamahenintsoa, E. (2013). Challenges and opportunities of higher education: Funding policies and programs in Madagascar. In D. Teferra (Ed.), Funding higher education in Sub-Sahara Africa (pp. I47-I83). London: Palgrave Macmillan.

Sall, A. (in press). Cheikh Anta Diop University. In D. Teferra (Ed.), Flagship universities in Africa: Achievements, successes, and potentials. Durban, South Africa, and Boston, Massachusetts, USA: International Network for Higher Education in Africa (INHEA).

Sifuna, D. (in press). University of Nairobi. In D. Teferra (Ed.), Flagship universities in Africa: Achievements, successes, and potentials. Durban, South Africa, and Boston, Massachusetts, USA: International Network for Higher Education in Africa (INHEA).

Teferra, D. 20I3. Introduction. In D. Teferra (Ed.), Funding higher education in Sub-Sahara Africa (pp. I-I2). London: Palgrave Macmillan.

Teferra, D. (20I3). The "soft power" proof of the pudding - Not in the branding. University World News, Issue 308. Retrieved on June 2, 20I4, from http://www.universityworldnews.com/article. php? story $=20140220125331356$.

UIS. UNESCO-Institute of Statistics (20II). Financing education in Sub-Saharan Africa: Meeting the challenges of expansion, equity and quality. Paris: UNESCO.
World Bank (20I0). Financing higher education in Africa. Washington, DC: World Bank.

Yigezu, M. (2013). Funding higher education in Ethiopia: Modalities, challenges, opportunities, and prospects. In D. Teferra (Ed.), Funding higher education in Sub-Sahara Africa (pp. 38-70). London: Palgrave Macmillan. 